\title{
Definitive Chemoradiation in Locally Advanced Squamous Cell Carcinoma of the Hypopharynx: Long-term Outcomes and Toxicity
}

\author{
ADITYA JULOORI ${ }^{1}$, SHLOMO A. KOYFMAN ${ }^{1}$, JESSICA L. GEIGER ${ }^{2}$, NIKHIL P. JOSHI ${ }^{1}$, \\ NEIL M. WOODY ${ }^{1}$, BRIAN B. BURKEY ${ }^{3}$, JOSEPH SCHARPF ${ }^{3}$, ERIC L. LAMARRE ${ }^{3}$, \\ BRANDON PRENDES ${ }^{3}$, DAVID J. ADELSTEIN ${ }^{2}$, JOHN F. GRESKOVICH ${ }^{1}$ and LANEA KELLER ${ }^{1}$ \\ Departments of ${ }^{1}$ Radiation Oncology, and ${ }^{2}$ Hematology and Oncology, Taussig Cancer Institute, Cleveland Clinic, and \\ ${ }^{3}$ Department of Otolaryngology, Head and Neck Institute, Cleveland Clinic, Cleveland, OH, U.S.A.
}

\begin{abstract}
Background/Aim: Definitive chemoradiation (CRT) is a common approach for locally advanced hypopharyngeal squamous cell carcinoma (SCC) with the goal of organ preservation. Reports on long-term oncologic and functional outcomes have been limited. This study reports on outcomes utilizing this approach at a single institution over 30 years. Materials and Methods: Medical records for patients with stage III-IVB SCC of the hypopharynx were retrospectively reviewed. Patient and disease-related factors were identified and analyzed for impact on overall survival (OS), cancer-specific survival (CSS), disease-free survival, distant failure, and locoregional failure. Results: A total of 54 patients were identified who were treated with definitive CRT to a mean dose of $72 \mathrm{~Gy}$. With a median follow-up period of 49.8 months, 5- and 10-year OS was $62 \%$ and $43 \%$ respectively. Five and 10-year CSS were $74 \%$ and $72 \%$ respectively. Ten-year local control was $78 \%$. Of the 37 patients with no treatment failure, 29\% experienced a grade 3 or higher late toxicity, with the majority resolving during continued long-term follow-up. Conclusion: This study demonstrates good outcomes with long-term follow-up with acceptable rates of late toxicities. The findings here represent the longest published median follow-up in this population and validate the strategy of organ preservation.
\end{abstract}

Squamous cell carcinoma (SCC) of the hypopharynx is a rare malignancy accounting for approximately $3-5 \%$ of head and

This article is freely accessible online.

Correspondence to: Aditya Juloori, MD, Department of Radiation Oncology, Taussig Cancer Institute, Cleveland Clinic, 9500 Euclid Ave, Cleveland, OH 44195, USA. E-mail: juloora@ccf.org

Key Words: Head and Neck cancer, hypopharynx, organ preservation, radiotherapy, chemotherapy, squamous cell carcinoma. neck SCC cases (1) with a yearly incidence of 3,400 new cases in the United States (2). The management of hypopharyngeal SCC remains complex due to the close proximity of the hypopharynx to the larynx and esophagus and the natural history of the disease. Only $25 \%$ of patients with hypopharyngeal SCC present with early-stage disease (T1-T2N0) (3) and in these patients, both surgery and definitive radiation have been associated with similar outcomes in terms of local control and functional outcomes $(1,4)$. Due to the late presentation of symptoms and rich lymphatic drainage of the hypopharynx, most patients present with locoregionally advanced disease at the time of their diagnosis. Traditionally the standard-of-care for patients presenting with advanced disease has included extirpative surgery followed by adjuvant radiation (RT) $(5,6)$. The ability to preserve the larynx, and thus help maintain the crucial functions of speech and respiration has increasingly become recognized as an important goal of definitive treatment. Therefore, definitive chemoradiotherapy (CRT) has become a common treatment strategy. Treatment with CRT has indeed noted an annual $2 \%$ increase in hypopharynx patients since 1988 , with over $70 \%$ of patients undergoing this treatment strategy in 2010 (7). Here, we present our long-term institutional experience of patients with locally advanced hypopharyngeal cancer treated with concurrent CRT over the past 30 years and examine the impact of this strategy on oncological outcomes and associated toxicity.

\section{Materials and Methods}

We queried the Cleveland Clinic's Institutional Review Board (IRB)-approved Head and Neck Cancers Registry for patients with hypopharyngeal carcinoma treated at our institution. Patients with histologically confirmed stage III-IVB SCC of the hypopharynx treated with definitive CRT from 1986 through 2013 were included. Patients with a history of prior major surgery of the neck or glottis, 
Table I. Patient characteristics.

\begin{tabular}{lcc}
\hline Characteristic & $\mathrm{N}$ & $\%$ \\
\hline Gender & 12 & \\
$\quad$ Female & 42 & 22.2 \\
$\quad$ Male & & 77.8 \\
Race & 10 & \\
$\quad$ African American & 42 & 18.5 \\
$\quad$ Caucasian & 2 & 77.8 \\
Other & 13 & 3.7 \\
Smoking history & 35 & 24.1 \\
$\quad$ 10 Pack-years & & 64.8 \\
$>10$ Pack-years &
\end{tabular}

metastatic disease, or a synchronous primary in the head and neck region were excluded. The medical chart was abstracted for data regarding patient presentation, demographics, tumor characteristics, and treatment-related outcomes. The collection, storage, and retrieval of data were all carried out in compliance with the hospital's IRB and the Health Insurance Portability and Accountability Act.

The Kaplan-Meier method was used to calculate the time to locoregional failure, distant failure, disease-free survival and overall survival (OS). Actuarial analysis was performed to estimate timespecific rates for these endpoints. Surviving patients were censored at their last clinical follow-up date. Cancer-specific survival (CSS) rates were calculated using competing risk analysis with death from other causes treated as a competing event. Rates for second malignancies were also calculated using competing risk analysis with all-cause mortality treated as a competing event. Cox proportional hazards regression was used to examine the association between locoregional failure and patient demographic, clinical, and treatment factors. A two-sided $p$-value less than 0.05 was considered to be statistically significant. All statistical analyses and plots were performed with SAS version 9.3 (SAS Institute, Cary, NC, USA).

\section{Results}

A total of 54 patients were identified [(median age $=60$ years, range $=42-74$ years), median KPS $=90$ (range $=70-100)$ ] with hypopharyngeal SCC treated with definitive CRT between 1986 and 2013 (Table I). The median follow-up was 49.8 months (range=1.9-184 months). Pathology confirmed SCC in $96 \%$ of samples, with one case identified as papillary SCC and one case identified as basaloid SCC. The majority of patients were Caucasian and male $(78 \%$ and $78 \%$, respectively) with greater than a 10 pack-year smoking history $(65 \%)$. All patients presented with American Joint Committee on Cancer [seventh edition (8)] stage III or IV disease. Approximately $46 \%(n=25)$ of patients presented with a T1/T2 tumor and approximately 54\% ( $\mathrm{n}=29)$ presented with a T3/T4 tumor (Table II). A minority of patients presented with early nodal disease [cN0: $\mathrm{n}=8(4.8 \%)$
Table II. TNM stage (AJCC 7th edition) (8) of patients with hypopharyngeal carcinoma.

\begin{tabular}{lcccccc}
\hline & \multicolumn{6}{c}{ N-Stage, $\mathrm{n}$} \\
\cline { 2 - 7 } T-Stage & N0 & N1 & N2a & N2b & N2c & N3 \\
\hline T1 & 0 & 0 & 0 & 3 & 1 & 4 \\
T2 & 0 & 4 & 2 & 5 & 4 & 2 \\
T3 & 3 & 5 & 2 & 2 & 0 & 3 \\
T4a & 4 & 2 & 1 & 3 & 2 & 1 \\
T4b & 1 & 0 & 0 & 0 & 0 & 0 \\
\hline
\end{tabular}

Table III. Characteristics of surgery, chemotherapy, and radiotherapy.

\begin{tabular}{lrr}
\hline Factor & N & $\%$ \\
\hline Chemotherapy & & \\
$\quad$ Cetuximab & 1 & 1.9 \\
Cisplatin & 2 & 3.7 \\
$\quad$ Cisplatin + 5FU & 49 & 90.7 \\
$\quad$ Other & 2 & 3.7 \\
Radiation & & \\
$\quad$ 3D-RT & 47 & 87.0 \\
IMRT & 7 & 13.0 \\
Radiation fractionation & 21 & 38.9 \\
$\quad$ BID & 33 & 61.1 \\
$\quad$ Daily & & \\
Elective lymph node dissection & 40 & 74.1 \\
$\quad$ No & 14 & 25.9 \\
$\quad$ Yes & & \\
Salvage surgery after LR (n=10) & 2 & 20.0 \\
$\quad$ No & 8 & 80.0 \\
$\quad$ Yes &
\end{tabular}

5FU: 5-Fluorouracil, IMRT: intensity-modulated radiation therapy, BID: twice daily, LR: local recurrence.

and $\mathrm{cN} 1: \mathrm{n}=110.3 \%$ )], with $64.8 \%$ presenting with $\mathrm{cN} 2$ disease and higher $(\mathrm{cN} 2: \mathrm{n}=25(46.2 \%)$ and $\mathrm{cN} 3: \mathrm{n}=10$ $(18.5 \%)]$.

Radiotherapy was delivered to the primary tumor and the bilateral necks via a conventional or 3D conformal RT technique in $87 \%(n=47)$; seven patients were treated with intensity-modulated radiotherapy (IMRT, Table III). The median RT dose was 72 Gy (range $=66-74.4 \mathrm{~Gy}$ ) and daily fractionation was utilized in $61.1 \%(\mathrm{n}=33)$. Twice-a-day fractionation was used for select patients (generally with T34 tumors) in the earlier years $(9,10)$. Most patients $(n=49$, $90.7 \%$ ) received concurrent chemotherapy consisting of cisplatin and 5-fluorouracil and $92.5 \%(\mathrm{n}=50)$ of all patients received two or more cycles of chemotherapy. Elective neck dissection was performed at the discretion of the treating 


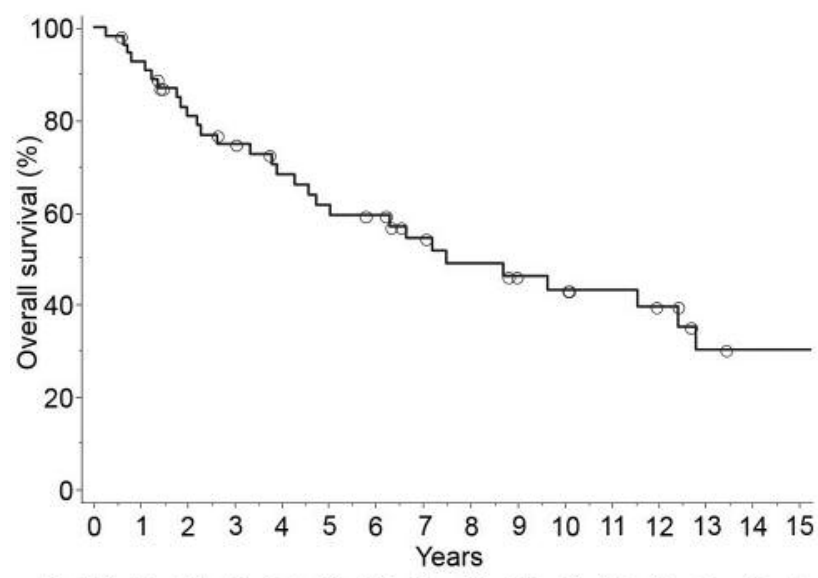

$\begin{array}{llllllllllllllll}N=54 & 49 & 41 & 36 & 31 & 28 & 26 & 21 & 18 & 15 & 14 & 12 & 10 & 6 & 5 & 5\end{array}$

Figure 1. Kaplan-Meier analysis of overall survival after definitive treatment for hypopharyngeal cancer.

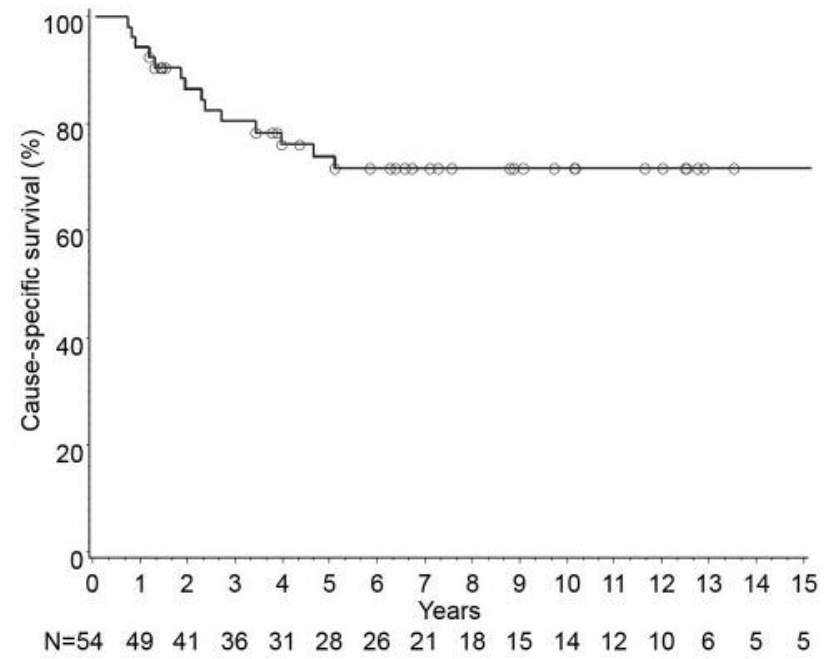

Figure 2. Kaplan-Meier analysis of cancer-specific survival after definitive treatment for hypopharyngeal cancer.

surgeon after definitive CRT in $25.9 \% \quad(n=14)$ of the population, all of whom had N2 or greater disease.

The median, 5-year, and 10-year OS for the study cohort was 7.5 years, $62 \%$ [95\% confidence interval $(\mathrm{CI})=48-75 \%$ ], and $43 \%(95 \% \mathrm{CI}=28-58 \%)$, respectively (Figure 1). The 5year and 10-year CSS for the study cohort was 74\% (95\% $\mathrm{CI}=62-86 \%)$ and $72 \% \quad(95 \% \quad \mathrm{CI}=59-84 \%)$, respectively (Figure 2). Thirty-nine patients were without evidence of disease at the last follow-up. There were 10 locoregional failures resulting in 5- and 10-year rates of local control

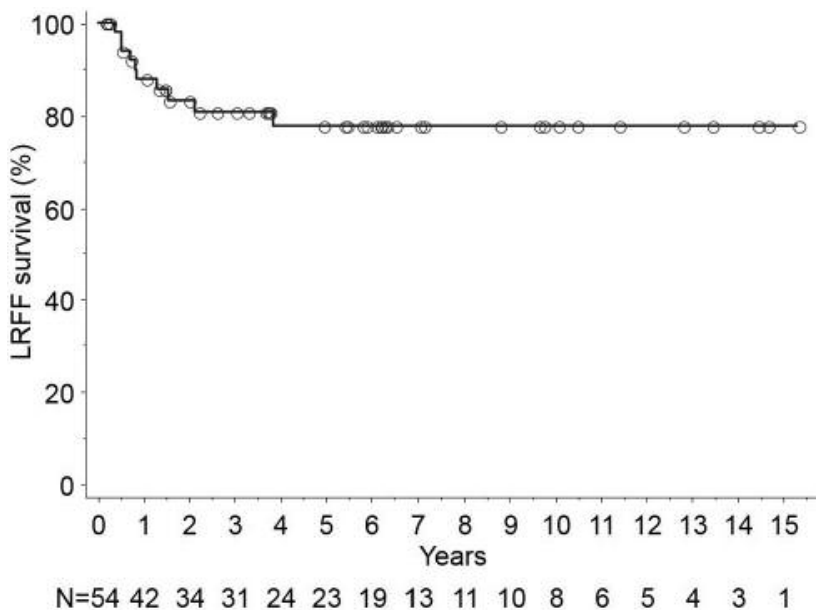

Figure 3. Kaplan-Meier analysis of locoregional failure-free (LRFF) survival after definitive treatment for hypopharyngeal cancer.

(Figure 3) both of 78\% (95\% CI=66-94\%). Surgical salvage after locoregional failure was attempted in eight patients, and was successful in three, resulting in a median survival after successful salvage surgery of 11.6 years. The median survival for patients with uncontrolled locoregional disease after salvage surgery was 4.8 months. Ten patients were noted to have distant metastases: one patient developed distant metastases at the time of local regional failure, two patients with locoregional failure subsequently developed distant metastases, and seven patients were noted to develop distant metastases without evidence of locoregional failure. The median survival for the seven patients with distant metastases only was 4.8 months. The 5- and 10-year rate of distant failure-free survival (Figure 4) was 76\% (95\% $\mathrm{CI}=63-89 \%)$. No examined demographic, clinical, or treatment related parameter was noted to predict for locoregional failure on univariate analysis (Table IV). Twelve patients $(22 \%)$ developed a second primary cancer, two of whom developed a second primary head and neck cancer. The cumulative 5- and 10- year rate of secondary malignancy was $14 \%(95 \% \quad \mathrm{CI}=4-24 \%)$ and $24 \%(95 \%$ $\mathrm{CI}=11-38 \%$ ), respectively (Figure 5).

Maximum toxicities as defined by the Common Terminology Criteria for Adverse Events (CTCAE) (11) are detailed in Table V. Of the 37 patients with no recurrence during the course of follow-up, 16 (29\%) patients experienced a grade 3 or higher late toxicity, with the majority (13/16) resolving in long-term follow-up. At the last follow-up of the 24 patients that required a feeding tube, seven remained dependent and nine required a limited diet without feeding tube dependence. Eighteen patients 


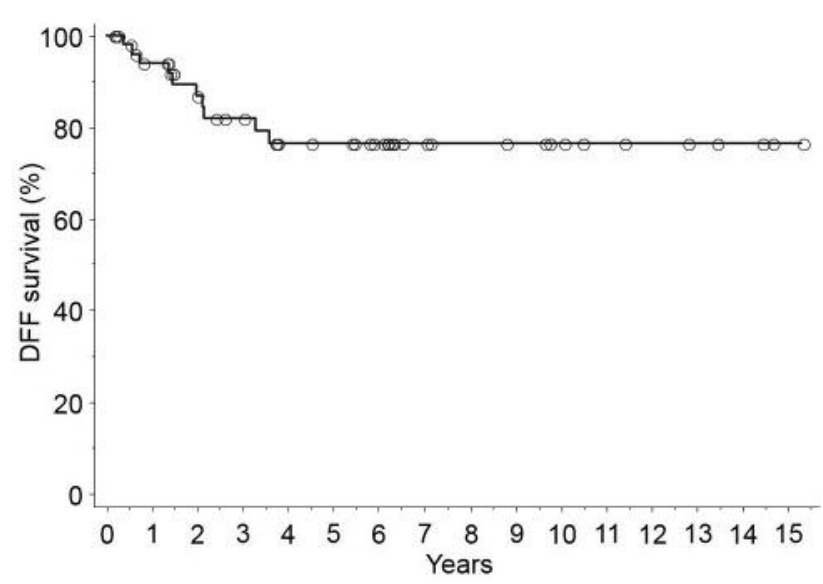

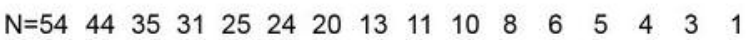

Figure 4. Kaplan-Meier analysis of distant failure-free (DFF) survival after definitive treatment for hypopharyngeal cancer.

experienced grade 3 dysphagia and 11 patients were noted to have grade 3 stricture requiring dilation. Eleven patients were noted to have grade 2 or higher aspiration. Two treatment-related deaths were noted from renal failure and aspiration pneumonia, resulting in a $3.7 \%$ mortality rate.

\section{Discussion}

The present study is a unique analysis of long-term survival and toxicity in a cohort of patients with locally advanced hypopharyngeal cancer treated with definitive CRT at a single institution over approximately 30 years. To our knowledge, this study represents the longest published median follow-up after definitive CRT for locally advanced hypopharyngeal cancer. Table VI displays comparative data from other published series showing outcomes for definitively treated patients. Our findings demonstrate that for select patients, CRT is a feasible and efficacious primary treatment strategy associated with excellent locoregional control and organ preservation. Furthermore, our OS and CSS outcomes compare favorably to other published surgical and definitive CRT series.

The 5-year rates of local control and freedom from distant metastases in the present study were $78 \%$ and $76 \%$ respectively, identical to the 10 -year rates, suggesting that a patient's disease course is primarily determined in the early years after treatment. Additionally, we noted equivalent rates of distant and primary failure differing from previous reports in the literature wherein locoregional failures were the main drivers of relapse $(12,13)$. In the present study, $22 \%$ of patients developed secondary primary cancer after treatment, with 5-and 10-year rates of secondary malignancy of $14 \%$

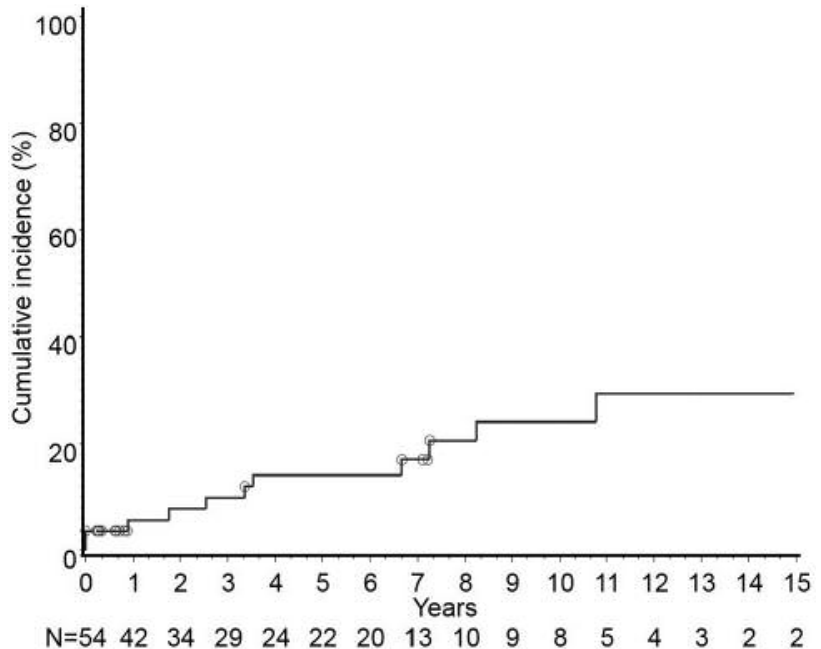

Figure 5. Cumulative incidence of second primary malignancy after definitive treatment for hypopharyngeal cancer.

Table IV. Univariate analysis of tumor and patient factors on locoregional failure. On Cox proportional hazards regression analysis, no clinical parameter (including age, $T, N$, stage, tumor differentiation, smoking status, alcohol use, and the use of hyperfractionation) was predictive of locoregional failure.

\begin{tabular}{lll}
\hline Variable & HR & $p$-Value \\
\hline Age at RT (continuous) & 1.00 & 0.91 \\
Female $v$. male & 1.57 & 0.51 \\
Current smoker $v s$. never/former smoker & 1.77 & 0.38 \\
Heavy alcohol use (yes $v s$. no) & 1.24 & 0.74 \\
Poorly differentiated $v s$. moderate & & \\
or well-differentiated & 3.62 & 0.13 \\
RT dose (continuous) & 0.83 & 0.39 \\
BID Fx $v s . Q D$ Fx & 1.38 & 0.61 \\
Stage T3T4 vs. T1T2 & 2.41 & 0.2 \\
Stage N2, N3 vs. N0, N1 & 1.28 & 0.72 \\
IVa $v s$. III & 3.41 & 0.25 \\
IVb $v s$. III & 0.96 & 0.98 \\
IVb $v s$. IVa & 0.28 & 0.23 \\
\hline
\end{tabular}

RT: Radiation therapy, $B I D$ : twice daily, $Q D$ : once daily.

and $24 \%$ respectively, consistent with previously reported rates of $20-26 \%$ in published studies $(3,14)$. The increased rate of secondary tumors underlines the importance of continued long-term follow-up in this patient population.

As the use of CRT rather than surgery has become the more common primary treatment strategy, there has not been an overall compromise in survival outcomes (7). Previous studies of patients with hypopharyngeal cancer from the Surveillance, Epidemiology and End Results database have demonstrated 
that use of definitive radiation (as opposed to patients treated with surgery alone or surgery with radiation) is the only modality in which OS has significantly improved since 1988. Five-year OS for patients treated with definitive radiation improved from $13.5 \%$ in $1988-1990$ to $23.7 \%$ in $2001-2005$ $(p<0.001)$ (7), likely reflecting improved radiation and imaging techniques over time. Published reports of patients with hypopharyngeal cancer patients treated with surgery alone show 5-year OS ranging from $24 \%$ to $33 \%$ (15-18).

The delivery and side-effect profile of RT has improved over the years with the development of IMRT, which has been shown to reduce the integral dose delivered to adjacent normal structures with resultant reduction in treatment related toxicities, such as xerostomia (19). Thus, the use of IMRT in the definitive treatment of head and neck carcinomas has become standard in recent years. Even further advances including the use of image-guided radiotherapy (IGRT) may help clinicians further refine their treatment volumes and set-up error. Given the time period over which our study was conducted, most (87\%) patients were treated via a 3D approach, with only $13 \%$ receiving IMRT. Perhaps our good overall outcomes are a result of high treatment compliance and aggressive supportive care.

Due to the close anatomic proximity of the hypopharynx to supraglottic larynx and pharyngeal constrictors, late toxicity, primarily dysphagia, remains a significant concern in patients treated with definitive radiation (20-23). In our series, $43 \%$ of patients experienced grade 3 or more late toxicity, with the majority resolving during long-term follow-up. A total of $35 \%$ of patients had severe late dysphagia and only $11 \%$ of patients who remained free of disease still required tube feeding at the last follow-up. Our Institution has historically utilized aggressive multidisciplinary evaluation and management of toxicity for patients with head and neck cancer, perhaps reducing the rate of long-term feeding tube dependency.

As a single-institution retrospective study, this study is certainly subject to inherent selection and recall bias, as well as being limited by a moderate sample size. The present study is also limited by lack of available data on p16 as human papilloma virus (HPV) tumor status is now widely recognized as an important prognostic factor in head and neck cancer, although the significance in hypopharyngeal cancer remains unclear.

In conclusion, this study demonstrated successful organ preservation with good oncological outcomes in the treatment of locally advanced hypopharyngeal cancer at our Institution over the past 30 years. Our findings underline the fact that some patients in this population will be long-term survivors and that extended follow-up and continued management of long-term toxicity is warranted. Future prospective studies utilizing IMRT, IGRT, dose escalation, and HPV status are needed to further improve therapeutic gains and limit treatment-related toxicities.
Table V. Toxicities after definitive chemoradiation according to toxicity grade by CTCAE guidelines.

\begin{tabular}{|c|c|c|c|}
\hline Toxicity & Grade/subgroup & Incidence & $\%$ \\
\hline \multicolumn{4}{|l|}{ Acute } \\
\hline \multirow{3}{*}{$\begin{array}{l}\text { Febrile neutropenia } \\
(\mathrm{n}=46)\end{array}$} & 0 & 30 & 65.2 \\
\hline & 3 & 15 & 32.6 \\
\hline & 4 & 1 & 2.2 \\
\hline \multirow{4}{*}{$\begin{array}{l}\text { Radiation dermatitis } \\
(\mathrm{n}=45)\end{array}$} & 1 & 17 & 37.8 \\
\hline & 2 & 15 & 33.3 \\
\hline & 3 & 10 & 22.2 \\
\hline & 4 & 3 & 6.7 \\
\hline \multirow[t]{4}{*}{ Pain $(n=45)$} & 0 & 2 & 4.4 \\
\hline & 1 & 3 & 6.7 \\
\hline & 2 & 37 & 82.2 \\
\hline & 3 & 3 & 6.7 \\
\hline \multirow[t]{2}{*}{ Feeding tube $(\mathrm{n}=54)$} & No & 19 & 35.2 \\
\hline & Yes & 35 & 64.8 \\
\hline \multirow[t]{3}{*}{ Feeding tube type $(\mathrm{n}=54)$} & Corpak & 10 & 18.5 \\
\hline & PEG & 24 & 44.4 \\
\hline & Total & 34 & 63.0 \\
\hline \multicolumn{4}{|l|}{ Late } \\
\hline \multirow{2}{*}{$\begin{array}{l}\text { Feeding tube resolution } \\
(\mathrm{n}=35)\end{array}$} & No & 8 & 22.9 \\
\hline & Yes & 27 & 77.1 \\
\hline \multirow{4}{*}{$\begin{array}{l}\text { Diet at last follow-up } \\
(\mathrm{n}=54)\end{array}$} & Feeding tube & 7 & 13.0 \\
\hline & Limited without supplements & 9 & 13.0 \\
\hline & Normal & 34 & 13.0 \\
\hline & Supplements needed & 4 & 13.0 \\
\hline \multirow[t]{3}{*}{ Xerostomia $(\mathrm{n}=47)$} & 0 & 3 & 6.4 \\
\hline & 1 & 8 & 17.0 \\
\hline & 2 & 36 & 76.6 \\
\hline \multirow[t]{4}{*}{ Dysphagia $(\mathrm{n}=50)$} & 0 & 14 & 28.0 \\
\hline & 1 & 13 & 26.0 \\
\hline & 2 & 5 & 10.0 \\
\hline & 3 & 18 & 36.0 \\
\hline \multirow[t]{4}{*}{ Fibrosis $(n=49)$} & 0 & 21 & 42.9 \\
\hline & 1 & 15 & 30.6 \\
\hline & 2 & 12 & 24.5 \\
\hline & 3 & 1 & 2.0 \\
\hline \multirow[t]{2}{*}{ Stricture $(n=50)$} & 0 & 33 & 66.0 \\
\hline & 3 & 17 & 34.0 \\
\hline \multirow[t]{4}{*}{ Osteonecrosis $(\mathrm{n}=49)$} & 0 & 45 & 91.8 \\
\hline & 1 & 1 & 2.0 \\
\hline & 2 & 1 & 2.0 \\
\hline & 3 & 2 & 4.1 \\
\hline \multirow[t]{3}{*}{ Trismus $(\mathrm{n}=50)$} & 0 & 39 & 78.0 \\
\hline & 1 & 9 & 78.0 \\
\hline & 2 & 2 & 78.0 \\
\hline \multirow[t]{4}{*}{ Voice changes $(n=51)$} & 0 & 14 & 27.5 \\
\hline & 1 & 28 & 54.9 \\
\hline & 2 & 6 & 11.8 \\
\hline & 3 & 3 & 5.9 \\
\hline \multirow[t]{3}{*}{ Neck pain $(n=49)$} & 0 & 34 & 69.4 \\
\hline & 1 & 3 & 6.1 \\
\hline & 2 & 12 & 24.5 \\
\hline \multirow[t]{4}{*}{ Aspiration $(n=49)$} & 0 & 37 & 75.5 \\
\hline & 1 & 1 & 2.0 \\
\hline & 2 & 5 & 10.2 \\
\hline & 3 & 6 & 12.2 \\
\hline
\end{tabular}


Table VI. Studies examining definitive radiation therapy in patients with hypopharyngeal cancer.

\begin{tabular}{|c|c|c|c|c|c|}
\hline Study (Ref) & Years & Cohort & $\begin{array}{l}\text { Median } \\
\text { follow-up }\end{array}$ & $\begin{array}{l}\text { Radiation } \\
\text { details }\end{array}$ & Outcomes \\
\hline Gupta et al. (24) & 1990-2004 & $\begin{array}{l}501 \text { Hypopharyngeal; } \\
83 \% \text { stage III/IV }\end{array}$ & 12 months & $\begin{array}{l}\text { Median dose } 70 \text { Gy in } \\
\text { parallel opposed fields }\end{array}$ & $\begin{array}{l}\text { 3-Year: LRC: } 47.1 \% \text {, } \\
\text { DFS: } 40.9 \%\end{array}$ \\
\hline Rabbani et al. (25) & $1964-2003$ & $\begin{array}{l}123 \text { Piriform sinus; } 80 \% \\
\text { stage III/IV (all T1 or T2) }\end{array}$ & 38.4 months & $\begin{array}{c}\text { Median dose } 74.4 \text { Gy (98\% in } \\
\text { parallel opposed fields, } 2 \% \text { IMRT) }\end{array}$ & $\begin{array}{l}\text { 5-Year: LRC: } 70 \% \\
\text { OS: } 35 \%\end{array}$ \\
\hline Mendenhall et al. (26) & 1964-2009 & $\begin{array}{l}170 \text { Pharyngeal wall; } 77 \% \\
\text { stage III/IV }\end{array}$ & 24 months & $\begin{array}{l}\text { 93\% Conventional RT (median } \\
\text { dose } 70 \text { and } 76.8 \text { Gy in daily and } \\
\text { BID schedule); } 7 \% \text { IMRT ( } 72 \text { Gy) }\end{array}$ & $\begin{array}{c}\text { 5-Year: CSS: } 49 \% \\
\text { for stage III and } \\
35 \% \text { for stage IV; } \\
\text { OS: } 31 \% \text { for stage III } \\
\text { and } 21 \% \text { for stage IV }\end{array}$ \\
\hline Studer et al. (27) & 2002-2008 & 65 Hypopharyngeal & 21 months & $\begin{array}{l}70 \text { Gy Using IMRT } \\
\text { (SIB technique) }\end{array}$ & $\begin{array}{l}\text { 2-Year LRC: } 77 \% \\
\text { OS: } 83 \%\end{array}$ \\
\hline Mok et al. (28) & $2000-2010$ & $\begin{array}{l}181 \text { Hypopharyngeal, } \\
\text { all stages }\end{array}$ & 60 months & $\begin{array}{l}50 \% \text { 3D-CRT; } \\
50 \% \text { IMRT }\end{array}$ & $\begin{array}{l}\text { IMRT: 3-Year LRC: } \\
\text { 75\%; 3-year OS 50\% } \\
\text { 3D-CRT: 3-Year: LRC } \\
\text { 58\%, OS: } 52 \%\end{array}$ \\
\hline Geretschlager et al. (29) & $2007-2010$ & $\begin{array}{l}50 \text { Patients ( } 26 \\
\text { hypopharyngeal, } \\
24 \text { laryngeal) }\end{array}$ & 50.4 months & Median dose 72 Gy, all IMRT & $\begin{array}{l}\text { 3-Year LRC: } \\
77 \% \text {, OS: } 63 \%\end{array}$ \\
\hline Current study & $1986-2013$ & $\begin{array}{l}54 \text { Hypopharyngeal; } \\
\text { all stage III or IV }\end{array}$ & 49.8 months & $\begin{array}{l}\text { Median dose } 72 \text { Gy; } \\
\text { 87\% 3D conformal, } 13 \% \text { IMRT }\end{array}$ & $\begin{array}{l}\text { Median survival: } \\
\text { 7.5 years 5-/10-Year: } \\
\text { OS: } 62 \% / 43 \% \\
\text { LRC: } 78 \% / 63 \%\end{array}$ \\
\hline
\end{tabular}

OS: Overall survival, DFS: disease-free survival, LRC: locoregional control; CSS: cancer-specific survival, IMRT: intensity-modulated radiation therapy, SIB: simultaneous integrated boost, BID: twice daily.

\section{References}

1 Takes RP, Strojan P, Silver CE, Bradley PJ, Haigentz M, Jr., Wolf GT, Shaha AR, Hartl DM, Olofsson J, Langendijk JA, Rinaldo A and Ferlito A: Current trends in initial management of hypopharyngeal cancer: The declining use of open surgery. Head Neck 34(2): 270-281, 2012.

2 Laryngeal and Hypopharyngeal Cancer. American Cancer Society 2015. http://www.cancer.org/cancer/laryngealandhypo pharyngealcancer/detailedguide/laryngeal-and-hypopharyngealcancer-key-statistics. Accessed 4/5/2015, 2015.

3 Spector JG, Sessions DG, Haughey BH, Chao KS, Simpson J, El Mofty S and Perez CA: Delayed regional metastases, distant metastases, and second primary malignancies in squamous cell carcinomas of the larynx and hypopharynx. Laryngoscope 111(6): 1079-1087, 2001.

4 Hall SF, Groome PA, Irish J and O'Sullivan B: Radiotherapy or surgery for head and neck squamous cell cancer: Establishing the baseline for hypopharyngeal carcinoma? Cancer 115(24): 5711-5722, 2009.

5 Kraus DH, Zelefsky MJ, Brock HA, Huo J, Harrison LB and Shah JP: Combined surgery and radiation therapy for squamous cell carcinoma of the hypopharynx. Otolaryngol Head Neck Surg 116(6 Pt 1): 637-641, 1997.

6 Zelefsky MJ, Kraus DH, Pfister DG, Raben A, Shah JP, Strong EW, Spiro RH, Bosl GJ and Harrison LB: Combined chemotherapy and radiotherapy versus surgery and postoperative radiotherapy for advanced hypopharyngeal cancer. Head Neck 18(5): 405-411, 1996.
7 Kuo P, Chen MM, Decker RH, Yarbrough WG and Judson BL: Hypopharyngeal cancer incidence, treatment, and survival: Temporal trends in the United States. Laryngoscope 124(9): 2064-2069, 2014.

8 AJCC Cancer Staging Handbook 7th Edition. Springer-Verlag: New York, 2010.

9 Horiot JC, Le Fur R, N'Guyen T, Chenal C, Schraub S, Alfonsi S, Gardani G, Van Den Bogaert W, Danczak S, Bolla M and Van Glabbeke $\mathrm{M}$ and De Pauw $\mathrm{M}$ : Hyperfractionation versus conventional fractionation in oropharyngeal carcinoma: Final analysis of a randomized trial of the EORTC cooperative group of radiotherapy. Radiother Oncol 25(4): 231-241, 1992.

10 Beitler JJ, Zhang Q, Fu KK, Trotti A, Spencer SA, Jones CU, Garden AS, Shenouda G, Harris J and Ang KK: Final results of local-regional control and late toxicity of RTOG 9003: A randomized trial of altered fractionation radiation for locally advanced head and neck cancer. Int J Radiat Oncol Biol Phys 89(1): 13-20, 2014.

11 Common Terminology Criteria for Adverse Events (CTCAE) v 4.0. 2018. https://evs.nci.nih.gov/ftp1/CTCAE/CTCAE_4.03/ Archive/CTCAE_4.0_2009-05-29_QuickReference_8.5x11.pdf. Accessed 4/30/2018, 2018.

12 Bataini P, Brugere J, Bernier J, Jaulerry $\mathrm{CH}$, Picot $\mathrm{C}$ and Ghossein NA: Results of radical radiotherapeutic treatment of carcinoma of the pyriform sinus: Experience of the institut curie. Int J Radiat Oncol Biol Phys 8(8): 1277-1286, 1982.

13 Johansen LV, Grau C and Overgaard J: Hypopharyngeal squamous cell carcinoma - treatment results in 138 consecutively admitted patients. Acta Oncol 39(4): 529-536, 2000. 
14 Nakamura K, Shioyama Y, Kawashima M, Saito Y, Nakamura N, Nakata K, Hareyama M, Takada T, Karasawa K, Watanabe T, Yorozu A, Tachibana H, Suzuki G, Hayabuchi N, Toba T and Yamada S: Multi-institutional analysis of early squamous cell carcinoma of the hypopharynx treated with radical radiotherapy. Int J Radiat Oncol Biol Phys 65(4): 1045-1050, 2006.

15 El Badawi SA, Goepfert H, Fletcher GH, Herson J and Oswald MJ: Squamous cell carcinoma of the pyriform sinus. Laryngoscope 92(4): 357-364, 1982.

16 Triboulet JP, Mariette C, Chevalier D and Amrouni H: Surgical management of carcinoma of the hypopharynx and cervical esophagus: Analysis of 209 cases. Arch Surg 136(10): 11641170, 2001.

17 Vandenbrouck C, Eschwege F, De la Rochefordiere A, Sicot H, Mamelle G, Le Ridant AM, Bosq J and Domenge C: Squamous cell carcinoma of the pyriform sinus: Retrospective study of 351 cases treated at the institut gustave-roussy. Head Neck Surg 10(1): 4-13, 1987.

18 Wang YL, Feng SH, Zhu J, Zhu GP, Li DS, Wang Y, Zhu YX, Sun GH and Ji QH: Impact of lymph node ratio on the survival of patients with hypopharyngeal squamous cell carcinoma: A population-based analysis. PLoS One 8(2): e56613, 2013.

19 Nutting CM, Morden JP, Harrington KJ, Urbano TG, Bhide SA, Clark C, Miles EA, Miah AB, Newbold K, Tanay M, Adab F, Jefferies SJ, Scrase C, Yap BK, A'Hern RP, Sydenham MA, Emson $\mathrm{M}$ and Hall E: Parotid-sparing intensity modulated versus conventional radiotherapy in head and neck cancer (PARSPORT): A phase 3 multicentre randomised controlled trial. Lancet Oncol 12(2): 127-136, 2011.

20 Eisbruch A, Harris J, Garden AS, Chao CK, Straube W, Harari PM, Sanguineti G, Jones CU, Bosch WR and Ang KK: Multiinstitutional trial of accelerated hypofractionated intensitymodulated radiation therapy for early-stage oropharyngeal cancer (rtog 00-22). Int J Radiat Oncol Biol Phys 76(5): 1333-1338, 2010.

21 Machtay M, Moughan J, Farach A, Martin-O'Meara E, Galvin J, Garden AS, Weber RS, Cooper JS, Forastiere A and Ang KK: Hypopharyngeal dose is associated with severe late toxicity in locally advanced head-and-neck cancer: An rtog analysis. Int J Radiat Oncol Biol Phys 84(4): 983-989, 2012.

22 Roe JW, Carding PN, Dwivedi RC, Kazi RA, Rhys-Evans PH, Harrington KJ and Nutting CM: Swallowing outcomes following intensity-modulated radiation therapy (IMRT) for head \& neck cancer- a systematic review. Oral Oncol 46(10): 727-733, 2010.
23 Pauloski BR, Rademaker AW, Logemann JA, Discekici-Harris M and Mittal BB: Comparison of swallowing function after intensitymodulated radiation therapy and conventional radiotherapy for head and neck cancer. Head Neck 37(11): 1575-1582, 2015.

24 Gupta T, Chopra S, Agarwal JP, Laskar SG, D’Cruz A K, Shrivastava SK and Dinshaw KA: Squamous cell carcinoma of the hypopharynx: Single-institution outcome analysis of a large cohort of patients treated with primary non-surgical approaches. Acta Oncol 48(4): 541-548, 2009.

25 Rabbani A, Amdur RJ, Mancuso AA, Werning JW, Kirwan J, Morris CG and Mendenhall WM: Definitive radiotherapy for t1t2 squamous cell carcinoma of pyriform sinus. Int J Radiat Oncol Biol Phys 72(2): 351-355, 2008.

26 Mendenhall WM, Morris CG, Kirwan JM, Amdur RJ, Vaysberg $\mathrm{M}$ and Werning JW: Definitive radiation therapy for squamous cell carcinoma of the pharyngeal wall. Pract Radiat Oncol 2(4): e113-119, 2012.

27 Studer G, Peponi E, Kloeck S, Dossenbach T, Huber G and Glanzmann C: Surviving hypopharynx-larynx carcinoma in the era of IMRT. Int J Radiat Oncol Biol Phys 77(5): 1391-1396, 2010.

28 Mok G, Gauthier I, Jiang H, Huang SH, Chan K, Witterick IJ, O'Sullivan B, Waldron JN, Bayley AJ, Cho BC, Cummings BJ, Dawson LA, Hope AJ, Kim JJ and Ringash J: Outcomes of intensity-modulated radiotherapy versus conventional radiotherapy for hypopharyngeal cancer. Head Neck 37(5): 655-661, 2015.

29 Geretschlager A, Bojaxhiu B, Dal Pra A, Leiser D, Schmucking M, Arnold A, Ghadjar P and Aebersold DM: Definitive intensity modulated radiotherapy in locally advanced hypopharygeal and laryngeal squamous cell carcinoma: Mature treatment results and patterns of locoregional failure. Radiat Oncol 10(1): 20, 2015.
Received April 1, 2018

Revised April 30, 2018

Accepted May 3, 2018 